\title{
ETNOBOTANI POHON DI DESA BUKIT BATU PADA AREAL HTI PT. BHATARA ALAM LESTARI KECAMATAN SUNGAI KUNYIT KABUPATEN MEMPAWAH
}

(Tree Ethnobotany in Bukit Batu Village in the HTI Area of PT. BHATARA Alam Lestari, Sungai Kunyit Subdistrict, Mempawah Regency)

\author{
Nurul Jamilah, Ratna Herawatiningsih, Siti Masitoh Kartikawati \\ Fakultas Kehutanan Universitas Tanjungpura Jalan Daya Nasional Pontianak 78124 \\ Email: nuruljamilamila@gmail.com
}

\begin{abstract}
This research aims to study the utilization and processing of tree species in daily activities by the community of Bukit Batu Village. Respondents is select using snowball sampling method, field observations and study literature. The results of the study are 22 types of tress from 15 family that been used by the socsiety of Bukit Batu village, Sungai Kunyit Subdistrict, Mempawah Regency. Of these 22 tree spescies divided into 4 groups including building 10 species, firewood 5 species, boat 7 species, and medicine1 species. The most widely used part of the tree is the stem 95\%, twigs and branches 22\%, and the laest used is the skin part which is as much as $4 \%$ by the people of Bukit Batu Village.
\end{abstract}

Keywords: Bukit Batu Village, ethnobotany, useful plants, snowball sampling

\section{PENDAHULUAN}

Indonesia yang beriklim tropis mempunyai tanah subur sehingga banyak jenis tumbuhan yang dapat tumbuh. Sejak jaman dahulu, manusia sangat mengandalkan lingkungan sekitarnya untuk memenuhi kebutuhannya. Kekayaan alam di sekitar kita sebenarnya sangat bermanfaat dan belum sepenuhnya digali, dimanfaatkan, atau bahkan dikembangkan (Sari, 2006). Masyarakat lokal sekitar hutan berinteraksi dengan hutan sejak ratusan tahun memiliki pengetahuan mengenai bagaimana menggunakan tumbuhan hutan secara berkelanjutan (Pei, 2013).

Etnobotani digunakan sebagai salah satu alat untuk mendokumentasikan pengetahuan masyarakat yang telah menggunakan berbagai macam manfaat tumbuhan untuk menunjang kehidupan seperti, pengobatan, bahan bangunan, upacara adat, budaya, dan lainnya (Setiawan et al. 2014). Potensi pohon merupakan salah satu data dan informasi penting yang diperlukan dalam pengembangan suatu model pengelolaan hutan potensi tersebut merupakan salah satu sumberdaya hutan yang banyak memberikan manfaat,karena hampir semua bagian dari pohon dapat dimanfaatkan (Arrijani, 2008). Pada masyarakat lokal, pengetahuan tentang manfaat tumbuhtumbuhan merupakan pengetahuan dasar yang amat penting dalam mempertahankan kelangsungan hidup 
mereka. Tetapi sejalan dengan berubahnya ekosistem tempat mereka hidup, perubahan lingkungan, komunikasi dan informasi dari luar, menyebabkan nilai-nilai budaya yang selama ini tumbuh dan berkembang di masyarakat ikut berkembang (Setyowati dan Wardah, 2007). Pengetahuan etnobotani banyak ditemukan dalam suku-suku tradisional di Indonesia yang merupakan hasil dari berinteraksi, berproses, dan bersikap melakukan pemanfaatan tumbuhan hutan. Pengelolaan hutan dengan pengetahuan tradisional untuk kelestarian hutan akan tercapai jika masyarakat lokal terlibat dalam kegiatan pengelolaan. Pengaruh perubahan dikhawatirkan akan menyebabkan semakin menurunnya pengetahuan tradisional atau bahkan menghilang. Hilangnya pengetahuan tradisional akan menyebabkan masyarakat lokal tidak lagi mengetahui cara mengelola sumber daya hutan secara lestari. Pengetahuan etnobotani merupakan salah satu indikator terhadap pemanfaatan tumbuhan hutan secara berkelanjutan. Penurunan pengetahuan etnobotani merupakan awal dari degradasi hutan karena menurunnya peran kelembagaan lokal dalam melakukan pemanfaatan hutan secara berkelanjutan (Pei et al. 2009). Penelitian mengenai pemanfaatan tumbuhan di Desa Bukit Batu pada areal HTI PT. Bhatara Alam Lestari Kecamatan Sungai Kunyit, Kabupaten Mempawah belum pernah diteliti. Oleh sebab itu, diperlukan kajian informasi dan pendokumentasian etnobotani pohon yang di manfaatkan oleh masyarakat, data mengenai pemanfaatan pohon oleh masyarakat dikawasan tersebut belum tergali dan belum ada penelitian. Kegiatan masyarakat dalam memanfaatkan hutan akan mengancam dan mengurangi keadaan jenis - jenis pohon yang kemungkinan termasuk jenis - jenis pohon yang selama ini terancam punah. Oleh karena itu, perlu dilakukan penelitian Etnobotani pohon di Desa Bukit Batu dengan tujuan pelestarian tumbuhan untuk mencegah terjadinya kepunahan spesies tumbuhan tersebut.

\section{METODOLOGI PENELITIAN}

Penelitian dilaksanakan di Desa Bukit Batu yang berada sekitar areal HTI PT Bhatara Alam Lestari Kecamatan Sungai Kunyit, Kabupaten Mempawah, dalam waktu selama \pm 3 minggu efektif dilapangan. Alat yang digunakan dalam penelitian ini diantaranya daftar pertanyaan kuisioner untuk responden terpilih, buku - buku identifikasi tumbuhan, alat tulis, serta kamera untuk dokumentasi. Adapun objek dalam penelitian ini yaitu masyarakat dan tumbuhan yang berada di Desa Bukit Batu Kecamatan Sungai Kunyit, Kabupaten Mempawah. Penelitian ini menggunakan Snowball sampling yaitu suatu metode dengan cara mengambil sejumlah kasus melalui hubungan keterkaitan dari satu orang dengan orang lain atau satu kasus dengan kasus lain, jadi metode ini kita menentukan responden kunci untuk kemudian menentukan responden yang lain berdasarkan informasi dari 
responden sebelumnya. Data yang digali meliputi jenis - jenis pohon, bagian yang digunakan dan keguanaan pohon tersebut kemudian dianalisis sehingga diperoleh hasil berupa gambaran secara sistematis dan akurat.

\section{HASIL DAN PEMBAHASAN}

\section{Karekteristik Responden}

Masyarakat yang menjadi responden dalam penelitian ini memiliki berbagai latar belakang yang berbeda, baik dari segi umur, pendidikan, maupun suku, berdasarkan hasil wawancara, diperoleh data dan informasi dari 16 responden yang diwawancarai. Responden berdasarkan suku diketahui bahwa masyarakat yang ada di Desa Bukit Batu yang menjadi responden terdiri dari beberapa suku, yaitu Suku Dayak Ahe 5 (31 \%), Melayu 9 (56\%), dan Bugis 2 (13\%). Persentase Suku bangsa responden diketahui bahwa Melayu merupakan suku terbesar dibandingkan dengan suku yang lain, yaitu sebanyak $56 \%$. Hal ini dikarenakan Desa Bukit Batu di dominasi Suku Melayu. Dalam pemanfaatan pohon berguna, Suku Melayu lebih sering intensitasnya dibandingkan dengan suku-suku yang lain.

Jumlah laki-laki responden yaitu $14(87 \%)$ dan perempuan yaitu 2 (13\%). Pengetahuan dan pemanfaatan pohon berguna antara laki-laki dan perempuan jauh berbeda. Hal ini dikarenakan perempuan yang ada di Desa Bukit Batu tidak banyak mengetahui pemanfaatan jenis pohon dalam kehidupan sehari-hari, baik untuk papan, kayu bakar, obat, dan perahu. Perbedaan yang terlihat jelas hanya pada pemanfaatan pohon pada kelompok kegunaan untuk papan, perahu dan kayu bakar.Dalam pemanfaatan untuk kategori ini, lakilaki lebih banyak menggunakan. Hal ini dikarenakan pekerjaan tersebut merupakan pekerjaan yang lazim dikerjakan oleh laki-laki.Dalam pemanfaatan pohon sebagai obat, perempuan sebagai ibu rumah tangga lebih sering menggunakan tumbuhan obat tersebut, responden berdasarkan kelas umur diperoleh 40-50 tahun. Hal ini karena pengetahuan mengenai pemanfaatan jenis pohon lebih banyak di usia tersebut.Tingkat pendidikan responden di Desa Bukit Batu bervariasi mulai dari SD dan SMA, tingkat pendidikan responden yang dimaksud dalam penelitian ini adalah pendidikan terakhir yang pernah atau telah ditempuh oleh masyarakatyang menjadi responden, sebagian besar masyarakat yang menjadi responden di Desa Bukit Batu adalah tamatan Sekolah Dasar SD sebnyak 15 responden (94\%), dan 1 responden tamatan tamatan SMA (6\%) responden dengan latar belakang pendidikan tamatan SD memiliki jumlah terbanyak pendidikan merupakan salah satu aspek penting dalam menunjang kualitas manusia. Latar belakang pendidikan yang rendah dari responden merupakan salah satu faktor penting terjadinya interaksi dalam masyarakat sekitar dengan 
sumberdaya yang terdapat di alam, karena latar belakang pendidikan berpengaruh terhadap pola pikir dan pola hidup seseorang. Hal ini akan berpengaruh pula pada pandangan dan pengetahuan responden mengenai berbagai pemanfaatan pohon.

\section{Jenis Pohon Yang Dimanfaatkan Oleh Masyarakat}

Penelitian yang dilakukan pada masyarakat Desa Bukit Batu di sekitar kawasan IUPHHK - HTI PT. BAL mendapatkan sebanyak 22 spesies pohon yang dikelompokkan kedalam 15 famili dan dibedakan kedalam empat kelompok kegunaan diantaranya untuk bahan bangunan (10 spesies), kayu bakar (5 speseis), perahu (7 spesies), dan obat (1 spesies). Uraian dari jenis pohon tersebut disajikan pada Tabel 1 .

Tabel 1.Spesies Pohon Berdasarkan Tingkat Kegunaan pada areal HTI PT.BAL ( Tree Species Based on The Level Of Use in the Area HTI PT. BAL)

\begin{tabular}{|c|c|c|c|c|}
\hline No & Nama Lokal & Nama Ilmiah & Family & Kegunaan \\
\hline 1 & Kemuning & Murraya paniculata & Rutaceae & Bangunan \\
\hline 2 & Kempas & Koompassia malaccensis maing & Caesal piniaceae & Bangunan \\
\hline 3 & Mengkayat & Dryobalanops spp & Dipterocarpaceae & Bangunan \\
\hline 4 & Temau & Cratoxylon arborescens BI & Guttiferae & Bangunan \\
\hline 5 & Tekam & Hopea dasyphyla V.SI & Dipterocarpaceae & Bangunan \\
\hline 6 & Kayu malam & Diospyrosmacrophylla BI & Ebenaceae & Bangunan \\
\hline 9 & Jongkang & Xylopia sp & Annonaceae & Bangunan \\
\hline 10 & Rengas & Gluta spp & Anacardiaceae & $\begin{array}{l}\text { Bangunan/ } \\
\text { Kayu Bakar }\end{array}$ \\
\hline 11 & Embun & Casuarinassumatrana jungh & Casuariaceae & Kayu bakar \\
\hline 12 & Perupuk & Lophopetalum spp & Celastraceae & Kayu bakar \\
\hline 16 & Meranti batu & Shorea dasyphylla Foxw & Dipterocarpaceae & Perahu \\
\hline 17 & Nyatoh & Madhuca sericeae H.I.L & Sapotaceae & Perahu \\
\hline 18 & Ramin & Gonystylus Bancanus Kurs & Thymeleaceae & Perahu \\
\hline 19 & Medang & Litsea $\mathrm{sp}$ & Lauraceae & Perahu \\
\hline 20 & Parak & Amara rubiginosa Hiem & Meliaceae & Perahu \\
\hline 21 & Resak & Vatica $\mathrm{spp}$ & Dipterocarpaceae & Perahu \\
\hline 22 & Ubah & Eugenia sp & Myrtaceae & $\begin{array}{l}\text { Obat Sakit } \\
\text { Perut }\end{array}$ \\
\hline
\end{tabular}

Jenis pohon berpotensi bahan kayu bakar, bangunan, dan perahu yang ditemukan di Desa Bukit Batu sebanyak 22 jenis terdiri 15 famili dengan jenis famili paling banyak adalah: Dipterocarpaceae, pemanfaatan pohon paling tinggi digunakan sebagai bahan bangunan yaitu : 10 jenis. Pemanfaatan untuk membuat perahu ada 6 jenis dan untuk bahan bakar ada 5 jenis sedangkan untuk obat ada 1 jenis. Spesies rengas (Gluta spp) dikenal dengan tumbuhan yang bersifat racun, tetapi di pedalaman Sulawesi buahnya dapat dimanfaatkan dengan cara dibakar terlebih dahulu kemudian baru bisa dimakan (Heyne, 1987). Akar pohon ubah Eugenia sp dimanfaatkan sebagai obat sakit pinggang (Johan Syah et al. 2011). Namun di Desa Bukit Batu kulit 
dari jenis pohon tersebut untuk mengobati sakit perut (Heyne, 1987). Menyatakan bahwa meranti batumenghasilkan damar yang dapat diperdagangkan untuk industry korek api, kembang api, cat dan lain-lain. Resak dapatmenghasilkan damar yang beraroma wangi dan bisa diolah menjadi bahan pewangi, dari dulu sudah diperdagangkan sampai ke Singapura. Famili pohon Dipterocarpaceae, merupakan jenis yang paling banyak digunakan oleh masyarakat Desa Bukit Batu dan yang paling banyak ditemukan. Dalam penelitian ini, jenis Dipterocarpaceae, yang ditemukan yaitu ressak (vetica spp), meranti batu Shorea dasyphylla dan lain - lain.

Beberapa jenis pohon tersebut diperoleh dari lapangan, ada jenis pohon yang dapat digunakan berbagai kegunaan seperti jenis pohon rengas (Glutaspp) sebagai bahanbangunan dan kayu bakar dan masih banyak lagi jenis pohon lain. Umumnya dari jenis- jenis pohon tersebut bagian yang digunakan sebagai bahan baku bangunan, kayu bakar, perahu, obat adalah batang, ranting, dahan, dan kulit atau bagianbagian jenis pohon antara lain yaitu : (batang, ranting, dan dahan, embun, rengas, perupuk, melaban dan lain lain) (batang; kempas, mengkayat dan lain - lain) (kulit: ubah).

\section{Pemanfaatan Berdasarkan Bagian Pohon}

Berdasarkan bagian pohon yang dimanfaatkan masyarakat sebagai obat, bangunan, kayu bakar, dan perahu dari bagian pohon yang manfaatkan masyarakat diketahui bahwa bagian yang banyak digunakan adalah batang dan yang paling sedikit adalah kulit. Persentase pohon berdasarkan bagian yang digunakan disajikan pada Gambar 1 .

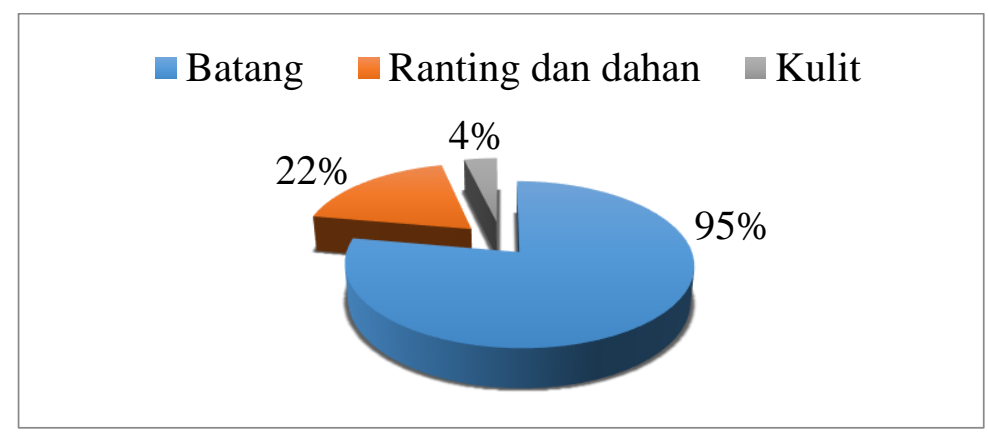

Gambar 1. Grafik persentase berdasarkan bagian yang digunakan (Graph of percentage of trees based on the part used)

Pemanfaatan spesies pohon sebagai obat, bangunan, kayu bakar, perahu ada beberapa spesies yang digunakan yaitu batang, ranting, dahan, dan kulit, dan lebih dari satu bagian yang digunakan. Berdasarkan hasil di lapangan tercatat 22 jenis pohon yang dapat ditemukan di
Desa Bukit Batu yang dimanfaatkan oleh masyarakat sekitar hutan tersebut sebagai obat, bangunan, kayu bakar, dan perahu. Dari seluruh spesies pohon yang digunakan masyarakat yang telah diketahui bagian pohon yang banyak digunakan yaitu pada bagian batang. 
Demikian dari masing - masing bagian pohon yang digunakan ternyata bagian batang 95\% lebih banyak dimanfaatkan oleh masyarakat sebagai kayu bakar, bangunan, dan perahu.

\section{Pohon Sebagai Bangunan}

Berdasarkan hasil wawancara dilapangan, diperoleh 10 jenis pohon yang dimanfaatkan oleh masyarakat suku Dayak dan Melayu sebagai bahan bangunan. Bangunan rumah di Desa
Bukit Batu adalah bangunan yang dibuat sifatnya menetap, jenis pohon yang digunakan oleh masyarakat memiliki kriteria: kuat, tahan terhadap rayap, dan tidak mudah lapuk dalam jangka waktu yang lama, bagian dari jenis pohon yang dimanfaatkan masyarakat adalah bagian batang. Adapun penggunaan pohon beserta bagian-bagian bangunan secara umum disajikan pada Tabel 2.

Tabel 2. Penggunaan Pohon Pada Bagian-Bagian Bangunan Oleh Masyarakat (Comomunity Use Of Trees In Parts Of The Building)

\begin{tabular}{|c|c|c|}
\hline No & Bagian Rumah & Nama Ilmiah \\
\hline 1 & $\begin{array}{l}\text { Kempas } \\
\text { Mengkayat }\end{array}$ & $\begin{array}{l}\text { Koompassia malaccensis } \\
\text { maing } \\
\text { Dryobalanops spp }\end{array}$ \\
\hline 2 & $\begin{array}{l}\text { Tekam } \\
\text { Kayu Malam }\end{array}$ & $\begin{array}{l}\text { Hopea dasyphyla V.SI } \\
\text { Diospyros macrophylla B }\end{array}$ \\
\hline 3 & $\begin{array}{l}\text { Temau } \\
\text { Pasir-pasir } \\
\text { Jongkang }\end{array}$ & $\begin{array}{l}\text { Cratoxylon arborescens BI } \\
\text { Stemonurus scorpiodes } \\
\text { Xylopia } \mathrm{sp}\end{array}$ \\
\hline 4 & $\begin{array}{l}\text { Kemuning } \\
\text { Kempas }\end{array}$ & $\begin{array}{l}\text { Murraya paniculata } \\
\text { Koompassia malaccensis } \\
\text { maing }\end{array}$ \\
\hline 5 & $\begin{array}{l}\text { Kemuning } \\
\text { Asam - asam } \\
\text { Mengkayat } \\
\text { Rengas }\end{array}$ & $\begin{array}{l}\text { Murraya paniculata } \\
\text { Mangifera } \mathrm{spp} \\
\text { Dryobalanops spp } \\
\text { Gluta spp }\end{array}$ \\
\hline \multicolumn{2}{|c|}{$\begin{array}{l}\text { Masyarakat di Desa Bukit Batu } \\
\text { memanfaatkan jenis pohon yang } \\
\text { berpotensi sebagai bahan bangunan } \\
\text { sebanyak } 10 \text { spesies. Namun, berbeda } \\
\text { dengan penelitian oleh (Elisa } \\
\text { Iswandono et al. 2015). Tumbuhan } \\
\text { yang digunakan sebagai bahan } \\
\text { bangunan hutan di Pegunungan Ruteng } \\
\text { sebanyak } 32 \text { spesies. }\end{array}$} & $\begin{array}{l}\text { wawancara dengan masyarakat, jenis } \\
\text { pohon yang dimanfaatkan oleh } \\
\text { masyarakat suku Melayu di Desa Batu } \\
\text { sebanyak (5 spesies) yaitu: rengas } \\
\text { (Gluta spp), embun (Casuarinas } \\
\text { sumatranajungh), } \\
\text { (Lophopetalumspp), melaban (Aporrosa } \\
\text { sphaerdopheramerr), } \\
\text { (Dactylocladus stenostachys). Dari jenis }\end{array}$ \\
\hline \multicolumn{2}{|c|}{ Pohon Sebagai Kayu Bakar } & -jenis pohon tersebut bagian yang \\
\hline $\begin{array}{l}\text { masy } \\
\text { men } \\
\text { untu }\end{array}$ & $\begin{array}{l}\text { lam kehidupan sehari-hari } \\
\text { akat Desa Bukit Batu masih } \\
\text { anakan kayu bakar sebagai alat } \\
\text { memasak. Berdasarkan hasil }\end{array}$ & $\begin{array}{l}\text { digunakan oleh masyarakat adalah } \\
\text { batang, dahan, dan ranting. } \\
\text { Menurut masyarakat, dari } 5 \text { jenis } \\
\text { pohon yang digunakan sebagai kayu }\end{array}$ \\
\hline
\end{tabular}


bakar memiliki kualitas yang sangat baik sebagai kayu bakar karena menghasilkan bara yang awet atau tidak cepat menjadi abu, tidak mudah pepes atau cepat habis, asap yang ditimbulkannya sedikit, dan memiliki kadar air yang rendah sehingga mudah dikeringkan. Berdasarkan hasil wawancara, jumlah jenis pohon yang digunakan sebagai kayu bakar oleh masyarakat Desa Bukit Batu lebih sedikit jika dibandingkan penelitian yang dilakukan oleh (Elisa Iswandono et al. 2015), terdapat 33 jenis tumbuhan yang digunakan sebagai kayu bakar oleh masyarakat hutan di Pegunungan Ruteng.

\section{Pohon Sebagai Obat}

Berdasarkan hasil wawancara, diperoleh 1 spesies pohon yang dimanfaatkan sebagai obat, mempunyai jumlah spesies sedikit jika dibandingkan dengan kelompok kegunaan lainnya.Spesies pohon sebagai obat yang digunakan oleh masyarakat suku Melayu di Desa Bukit Batu, yaitu: ubah (Eugenia sp), pemanfaatan bagian dari (Eugenia sp) adalah kulit batang, dengan cara pengolahannya, kulit batang dikeringkan kemudian direbus dan air hasil rebusan diminum, dipercaya dapat mengobati sakit perut.

Pemanfaatan pohon sebagai obat oleh masyarakat Desa Bukit Batu hanya 1 jenis karena masyarakat lebih sering memakai obat modern ketika sakit, hal ini dikarenakan obat modern dinilai lebih efisien.Selain itu masyarakat lebih suka pergi ke puskesmas, karena mudah dan cepat penanganannya. Berdasarkan hasil wawancara, jumlah jenis pohon yang digunakan sebagai obat yang dimanfaatkan oleh masyarakat Desa Bukit Batu lebih sedikit jika dibandingkan penelitian yang dilakukan oleh (Elisa Iswandono et al. 2015). Terdapat 73 jenis tumbuhan hutan di Pegunungan Ruteng.

\section{Pohon Sebagai Perahu}

Hasil wawancara terdapat 7 jenis kayu yang umumnya digunakan oleh masyarakat suku Melayu dan Bugis di Desa Bukit Batu. Penggunaan perahu adalah sebagai sarana penyebrangan sungai atau mencari ikan di tepi laut.Penggunaan jenis kayu untuk membuat perahu dibagi ke dalam bagian-bagian perahu yaitu bagian badan perahu, semang dan pasak, untuk badan perahu digunakan jenis kayu yang kuat, tidak mudah pecah, tidak berlubang, mudah terapung serta tahan terhadap perusak kayu khususnya binatang laut/air.

Terdapat lima jenis kayu yang biasa digunakan untuk bagian badan perahu yaitu: meranti bunga (Shorea leprosula), meranti batu (Shorea dasyphylla foxw), nyatoh (Madhuca sericeae H.I.L), ramin (Gonystylus bancanus kurs), medang (Litsea sp). Pasak atau paku adalah merupakan kayu yang menghubungkan semang di sebelah kiri dan kanan, kayu yang digunakan adalah kayu yang kuat, keras dan tidak mudah patah, karena posisi pasak yang selalu menahan badan perahu. Jenis kayu yang biasa digunakan untuk bagian pasak dan 
semang yaitu; parak (Amara rubiginosahiem), resak (Vaticaspp). Dari jenis-jenis pohon tersebut yang dimanfaatkan oleh masyarakat bagian yang digunakan adalah bagian batang. Jumlah jenis pohon yang digunakan untuk bahan baku perahu yang dimanfaatkan oleh masyarakat Desa Bukit Batu lebih sedikit, jika dibandingkan dengan suku Yaphai di Papua yang memanfaatkansekitar 26 jenis (Lanoeroe et al. 2005).

\section{Upacara Adat}

Upacara adat dalam masyarakat Dayak Ahe di Desa Bukit Batu tidak dapat dipisahkan dari sistem kepercayaan dan religi. Perwujudannya direalisasikan melalui upacara Adat, agar mendapatkan pertolongan jubata (Yang Maha Kuasa), dan percaya adanya pencipta alam semesta, terhadap roh - roh, dan kekuatan gaib pada benda- benda yang dianggap keramat. Oleh sebab itu, untuk menghormati roh - roh dan kekuatan gaib, masyarakat mengadakan upacara adat salah satunya yang terdapat dilapangan yaitu : Nubah upacara pembukaan hutan tanaman industri, upacara ini bermakna sebagai bentuk perlindungan diri pada saat bekerja di hutan, sebelum upacara dilaksanakan terdapat serangkaian tahapan pelaksanaan, yaitu: Nyangahathnmanta' pelantunan doa atau mantra, dan paraga yang sudah tersedia yaitu tempayan naga sebagai simbolis, maknanya bahwa hutan tersebut sudah ada yang mengelola, upacara dipimpin oleh seorang tetua adat, atau tetua kampung, sebagai pemimpin ritual, yang akan memanjatkan doa - doa dan mantra kepada roh para leluhur di dalam bahasa Dayak pembacaan doa diakhiri dengan acara makan bersama, dimana hidangan dan pangan disajikan sebagai santapan. Namun, berbeda pada penelitian (Asnawi, 1992). Upacara tradisional yang dilaksanakan oleh Suku Banjar adalah upacara "manaradak", upacara "manuping", upacara "manyanggar danau", upacara "manyanggar banua", upacara "maarak kitab bukhari", upacara "bamuludan", upacara "batajak" rumah, upacara yang berkaitan dengan peristiwa alam, dan upacara yang berkaitan dengan daur hidup. Misalnya untuk hiasan upacara digunakan, mayang bungkus, mayang urai, beringin kurung, dan lain-lain. Tumbuhan bagi orang Banjar tidak hanya digunakan untuk upacara adat, tetapi juga digunakan untuk kekuatan ilmu hitam dan penangkis ilmu hitam itu sendiri. Dengan demikian upacara itu sendiri sebenarnya untuk mendatangkan kesejahteraan bagi pelaksananya baik kerabat maupun masyarakat dan kampungnya.

\section{Kesimpulan}

Dari hasil penelitian terdapat 22 jenis pohon dari 15 famili yang dimanfaatkan oleh masyarakat, dan 12 famili rata - rata setiap famili hanya terdiri dari 1 spesies, terkecuali untuk famili Dipterocarpaceae 5 spesies, Myrtaceae 3 spesies, dan Anacardiaceae 2 spesies. Pemanfaatan bervariasi mulai dari pemanfaatan kayu bakar, bangunan, perahu, dan obat. 
Bagian jenis pohon yang dimanfaatkan meliputi batang, kulit, dahan dan ranting. Batang adalah bagian yang banyak digunakan yaitu $95 \%$.

\section{Saran}

Perlu dilakukan penelitian lebih lanjut mengenai pohon yang bermanfaat sebagai obat untuk mengetahui kandungan yang terdapat pada pohon tersebut sehingga pemanfaatannya akan terkendali dan aman digunakan oleh masyarakat

\section{DAFTAR PUSTAKA}

Arrijani. 2008. Struktur dan Komposisi Vegetasi Zona Montana Taman Nasional Gunung Gede Pangrango.Biodiversitas 9 (2) : 134-141

Asnawi A. 1992. Peranan tumbuhan dalam upacara daur hidup Suku Bangsa Banjar. Di dalam : Seminar dan Lokakarya Nasional Etnobotani; Cisarua-Bogor, 19-20 Februari 1992. Bogor: Departemen Pendidikan dan Kebudayaan RI, Lembaga Ilmu Pengetahuan Indonesia, Perpustakaan Nasional RI. Bogor. Hal: 202-215.

Heyne K. 1987. Tumbuhan Berguna Indonesia I-IV. Badan Penelitian dan Pengembangan Kehutanan. Departemen Kehutanan. Jakarta.

Johan S, Fadilah U \& Fathul Y. 2014. Studi Etnobotani Tumbuhan Obat Yang Di Manfaatkan Masyarakat Dusun Nekbare Desa Babane. Jurnal Hutan Lestari. 2 (3) : 419 426.

Lanoeroe S, Elisa MK \& Yohanes YR. 2005. Pemanfaatan jenis tumbuhan berkayu sebagai bahanbaku perahu tradisional oleh
Suku Yachai di Kabupaten Mappi. Biodiversitas. 6 (3), 212-216.

Elisa I, Ervizal AMZ, Agus H \& Nandi K. 2015. Pengetahuan Etnobotani Suku Manggarai dan Implikasinya Terhadap Pemanfaatan Tumbuhan Hutan di Pegunungan Ruteng. Jurnal Ilmu Pertanian Indonesia (JIPI). 20 (3): 171-181

Nurdiani N. 2014. Teknik Sampling Snowball Dalam Penelitian Lapangan. 5 (2): 1110-1118.

Pei SJ, Zhang G \& Huai H. 2009. Application of Traditional Knowledge in Forest Management: Ethnobotanical Indicator of Sustainable Forest Use. Forest Ecology and Management. 257 (10).

Pei SJ. 2013. Ethnobotany and Sustainable Use of Biodiversity. Plant and Diversity Resources. 35 (4): 401- 406.

Sari LORK. 2006. Pemanfaatan Obat Tradisional dengan Pertimbangan Manfaat dan Keamanannya. Majalah Ilmu Kefarmasian. 3 (1) :1-7.

Setiawan H \& Qiptiyah M. 2014. Kajian etnobotani masyarakat adat Suku Moronene di Taman Nasional Rawa Aopa Watumohai. Jurnal PenelitianKehutanan Wallacea. 3 (2), 107-117.

Setyowati FM \& Wardah. 2007. Keanekaragaman Tumbuhan Obat Masyarakat Talang Mamak di Sekitar Taman Nasional Bukit Tigapuluh, Riau. Biodiversitas. 8 (3): 228 232. 